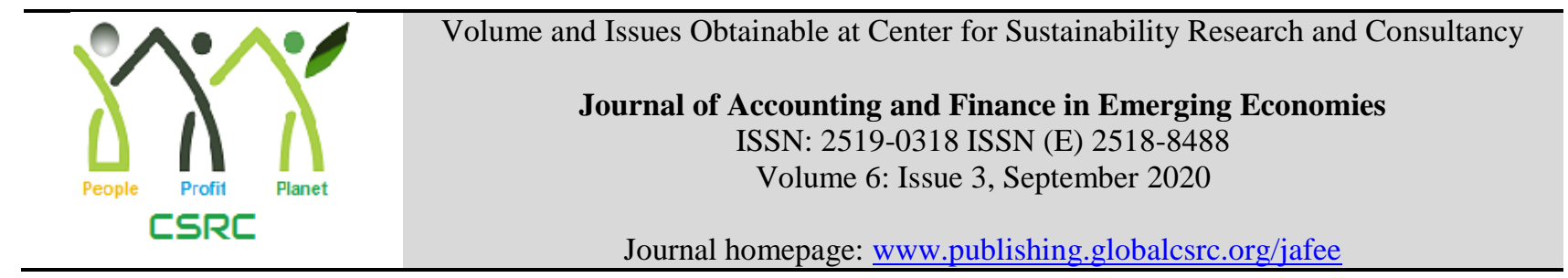

\title{
Effect of Financial Assistance on the Motivation and Satisfaction of Students with Disabilities at University Level in Punjab
}

\author{
${ }^{1}$ Ghulam Fatima, ${ }^{2}$ Samina Ashraf, ${ }^{3}$ Rukhsana Bashir, ${ }^{4}$ Noreen Rafiq \\ ${ }^{1}$ Associate Professor, Institute of Education and Research, University of the Punjab, Lahore-Pakistan \\ fatima.ier@pu.edu.pk \\ ${ }^{2 \& 3}$ Assistant Professor, Department of Special Education, University of the Punjab, Lahore-Pakistan \\ samina.dse@pu.edu.pk,rukhsana.dse@pu.edu.pk \\ ${ }^{4}$ M.Phil Scholar, Institute of Education and Research, University of the Punjab, Lahore-Pakistan
}

\section{ARTICLE DETAILS}

\section{History}

Revised format: August 2020

Available Online: September 2020

\section{Keywords}

Financial assistance, motivation, satisfaction, students with disabilities

\section{JEL Classification} MO, M40

\section{ABSTRACT}

Education is an essential investment in future employability, life fulfillment and motivation designed for students with disabilities (differently abled students). Most, nonetheless, are not able to invest and require external financial assistance. The study was aimed to identify the effect of financial assistance being provided to students with disabilities enrolled in public and private sector universities in the province of Punjab on their motivation and satisfaction. The population of this paper consisted of all students with disabilities (hearing impaired, visually impaired and physically handicapped) who were receiving higher education in public and private sector universities in Punjab. The samples comprised 56 students who were differently abled and had auditory, visual or physical impairment. These students were conveniently taken from three public and three private sector universities located in the Punjab. Data were collected through a self-developed questionnaire containing twenty-three statements measuring the effect of monetary assistance on the motivation and contentment of university students. Reliability index of the instrument was (Cronbach alpha $\alpha=.95$ ). Descriptive statistics, independent sample t-test, Analysis of variance (ANOVA) was applied to analyze the data. Major findings revealed that financial assistance was having a significant positive effect on the motivation and contentment of students having disabilities. Conclusions were drawn and recommendations were made to the Government of the Punjab for making the process of providing financial support to the students with disabilities more transparent and fast.

Corresponding author's email address: fatima.ier@ @u.edu.pk

Recommended citation: Fatima, G., Ashraf, S., Bashir, R., \& Rafiq, N. (2020). Effect of Financial Assistance on the Motivation and Satisfaction of Students with Disabilities at University Level in Punjab. Journal of Accounting and Finance in Emerging Economies, 6(3), 693-702 


\section{Introduction}

Monetary assistance is a collaboration amongst the student, guardians, educational institutes of postsecondary level, state and federal governments, and existing private capital. For the student who is differently abled, the collaboration also may include a Vocational Rehabilitation Agency and the Social Security Administration. This collaboration requires support from all entities and an apprehension of their distinctive errands within the monetary aid process (Financial Aid for Students with Disabilities, 2015). People with disabilities have higher rates of unemployment than those without disabilities (Bureau of Labor Statistics, 2012), however, those who are able to attain higher levels of education also reach higher rates of employment (Smith, Grigal, \& Sulewski, 2012). The higher employment rates after educational attainment are promising. However, the higher education degree financially is not viable for students with disabilities. These students remain an underrepresented but growing population in higher education (NCES, 2016; Newman, Wagner, Cameto, Knokey, \& Shaver, 2010), with approximately 80\% of students who are differently abled aspiring to pursue postsecondary education (Newman et al., 2011). A potential barrier that disabled students face when entering postsecondary education is the financial cost surrounding a degree.

The families of differently abled student are unevenly represented in the lowest income quartile (Wolanin, 2005), making financial aid even more vital for access opportunities. For low-socio economic status (SES) families of students having disabilities, expectations for postsecondary schooling are greatly diminished (Madaus et al., 2014). This relationship is particularly troubling since lower expectations for this population have been found to lead to lower academic and career outcomes (Wagner, Newman, Cameto, Levine, \& Marder, 2007). The four umbrella categories of aid students and their families can use are loans, grants, work-study, and tax benefits. Under the loans umbrella, students can pursue private loans or one or more federal loans including: Perkins, subsidized Stafford, unsubsidized Stafford, and parent PLUS (Bittinger, 2016). Grants include a number of federal grants such as Pell as well as state, institutional, and private/employer grants. Funds from both loans and grants will be available to students once they begin their education. The amount that can be earned from work-study opportunities is also disclosed to students once they begin.

Small amount of researches have been conducted regarding the motivation and satisfaction in relation to financial assistance of students with disabilities (Hasan, Malik \& Khan, 2013; Kundu, Dutta, Schiro-Geist \& Crandall, 2003; O'Shea \& Meyer, 2016). Self-Determination Theory (SDT) is a wide-ranging theory that put forth the context for apprehending the human behavior, and role of motivation and the way humans respond in different scenarios (Ryan \& Deci, 2000). The fundamental tenet of the theory is that relatedness, autonomy and competence are the basic inborn psychological needs that are central to adaptive impulse and human development (Deci \& Ryan, 2008).if their needs are not fulfilled they tend to feel coerced and agitated either externally or internally. According to McGuire, Norlander and Shaw (1990) there is a dearth of research to support the endowment and utility of facilities regarding disabilities. Therefore, the evaluation of such services vi-a-vis student motivation and satisfaction is near to impossible.

According to the statistics of World Health Organization (WHO), around fifteen percent of global population is suffering from some disability (February 10, 2015), however the occurrence of disability in Pakistan is $2.49 \%$ as assessed by the Population Census (1998). To make an all rounded and well researched policy, all disability related aspects like limited participation, restricted activity, health problems and environmental factors should be taken into account. Such over arcing information retrieval is lacking in Pakistan as it does in several other developing countries. Pakistan lacks the availability of systematic procedure and instrument for gathering disability related information from the diverse and huge population. In July 2011, Pakistan approved the UN Convention for the Rights of Persons with Disabilities (CRPD, Article 31). There are $19 \%$ physically disabled, mentally retarded stands around 14\%, multiple disabilities are $8.21 \%, 8.6 \%$ are visually impaired, while auditory impairment was measured to have affected $7.40 \%$ of the population and others are $43.33 \%$.

The National Policy for Persons with Disabilities (2002) was framed with the backdrop of data provided by WHO estimated that 10 percent of the adults and children are disabled in Pakistan. A more comprehensive report was provided by National Census, 1998. The estimate of National Census was $2.49 \%$ of the total population that was low as compared to the WHO report. 2.49\% estimation has been grouped as under into age specific groups according to the optimum level of requirement: 


\begin{abstract}
Children less than five who need assistance along with their families
Children in the age bracket of 5 to 14 years who require some type of special education

Youngsters up to the 29 years of age who need employment opportunities, specific training and further education

Adults who are disabled and need help

Senior disabled citizens who want special aids

$10.34 \%$

$23.09 \%$

$23.98 \%$

$25.15 \%$

$16.56 \%$

The needs and wants of differently abled college and school going students were not met and were not in accordance with the facilities provided to the other students . Getzel and Kregel (1996) found that the problems faced by the disabled student body in getting access to the facilities is not because of institutional inability, but it is due to the lack of identifying these needs. (McGuire, Norlander \& Shaw, 1990) suggested that due to the dearth of research related to disabled people it is cumbersome to monitor the student satisfaction level. DeFur, Getzel and Trossi (1996) and Parker and Szymanski (1998) said that the outcomes of disability related services can be monitored qualitatively and quantitatively by accessing student's satisfaction with academic, extra academic and professional lives transition of students at postsecondary institutions. This data can be positively used for recruiting, training and hiring for future. The investigation of the financial assistance being provided to students with disabilities, their motivation and satisfaction is the need of the hour. Therefore, current study is an attempt to investigate the influence of monetary aid on enthusiasm and gratification of students having disabilities at university level in the Punjab province of Pakistan.
\end{abstract}

\title{
2. Study Objectives
}

Following are the objectives of this study:

1. To identify the level of perceived effect of monetary aid on the enthusiasm of students with disabilities at university level in Punjab.

2. To identify the level of perceived effect of monetary aid on the gratification of students having disabilities at university level in Punjab.

3. To distinguish the level of perceived effect of monetary aid on the enthusiasm and satisfaction of students having disabilities at university level in Punjab on the basis of demographical variables (gender, locale, program, university, \& level of education).

\section{Research Hypotheses}

$\mathbf{H}_{1}$ 1: There is a considerable statistical difference in the perceived effect of financial assistance received by male and female students with disabilities on their motivation and satisfaction at university level in Punjab.

$H_{1}$ 2: There is a considerable statistical difference in the perceived effect of financial assistance being provided to rural and urban area students with disabilities on their motivation and satisfaction at university level in Punjab.

$H_{1}$ 3: There is a statistically major difference based on the level of education in the perceived effect of monetary aid on the enthusiasm and gratification of students having disabilities at university level in Punjab.

$\mathbf{H}_{1}$ 4: There is a statistically significant difference in terms of university in the perceived effect of monetary aid on the enthusiasm and gratification of disabled students at university level in Punjab.

H1 5: There is a statistically significant difference with respect to program in the perceived effect of monetary aid on the enthusiasm and gratification of students with disabilities in Punjab at university level.

\section{Research Design}

It was a quantitative study based on a descriptive research. Cross-sectional survey method has been used to investigate the effect of monetary aid on the enthusiasm and gratification of disabled students at university level in Punjab.

\subsection{Population of the Study}

The study population comprised all students with disabilities (hearing impaired, visually impaired and physically handicapped) who were receiving higher education in the public and private sector universities in Punjab. It is important to clarify that the disability of mental retardation was not mentioned as these students could not access the 
higher education level due to their limited mental faculties.

\subsection{Sample}

A sample of 56 disabled students including auditory, visual and physical impairment was conveniently taken from three public and three private sector universities located in the Punjab. Fifty six students with disabilities (males $=36$, females=20) were enrolled in six universities including University of the Punjab, Lahore (N=22), Lahore College for Women University, Lahore ( $\mathrm{N}=2$ ), University of Management and Technology, Lahore (N=7), Government College University, Lahore ( $\mathrm{N}=16)$, Government College University, Faisalabad $(\mathrm{N}=6)$, Allama Iqbal Open University, Islamabad $(\mathrm{N}=3)$. Out of 56 students, 50 were from urban, and six were from rural areas of the Punjab and their age range was between 20-30 years. The monthly income of their families was between Rs. 10,000-200,000. These participants were from M.A. Special Education ( $\mathrm{N}=32)$, Islamic studies $(\mathrm{N}=2)$, Law $(\mathrm{N}=3)$, History $(\mathrm{N}=5)$, English $(\mathrm{N}=8)$, Economics $(\mathrm{N}=4)$, Urdu $(\mathrm{N}=2)$. Out of 56, 37 participants were from M.A. program, nine were from M.Phil and one student was enrollrd in Ph.D.

\subsection{Instrument}

A questionnaire was developed on the basis of literature review which was authorized by a board of three experts. At the initial stage, a pool of 31 statements to measure the effect of monetary aid on gratification and enthusiasm of the students having disabilities was generated. All the statements of the questionnaire were rated on the five point likert scale from strongly agree 5 to strongly disagree 1.After the pilot study, the statements which did not contribute to increase the questionnaire's reliability were omitted. Afterwards, the reliability index (Cronbach Alpha) of the questionnaire including 24 statements was $\alpha=.95$.

\subsection{Procedure of Data Collection}

Researchers gathered the data by personally visiting students with disabilities (hearing impaired, visually impaired and physically handicapped) after taking prior consent of the heads of the concerned university.

\section{Data Analysis}

Descriptive (mean, standard deviation) and inferential statistics (independent sample t-Test and one- way ANOVA) were applied for analyzing data.

\section{Table 1: Demographic Characteristics of the Sample}

\begin{tabular}{|c|c|c|c|}
\hline Variables & Category & Number & Total \\
\hline & Male & 36 & 56 \\
\hline Gender & Female & 20 & \\
\hline \multirow{2}{*}{ Area } & Urban & 50 & 56 \\
\hline & Rural & 6 & \\
\hline \multirow{7}{*}{ Program } & M A Special Education & 32 & 56 \\
\hline & Islamic Studies & 2 & \\
\hline & Law & 3 & \\
\hline & History & 5 & \\
\hline & English & 8 & \\
\hline & Economics & 4 & \\
\hline & Urdu & 2 & \\
\hline \multirow{6}{*}{ University } & PU & 22 & 56 \\
\hline & LCWU & 2 & \\
\hline & UMT & 7 & \\
\hline & GCU Lahore & 16 & \\
\hline & GCU Faisalabad & 6 & \\
\hline & AIOU & 3 & \\
\hline Age range & $20-40$ & & 56 \\
\hline Monthly Income & $10,000-200,000$ & & 56 \\
\hline \multirow{3}{*}{ Education } & MA & 37 & 56 \\
\hline & M PHIL & 9 & \\
\hline & PH D & 1 & \\
\hline
\end{tabular}

Note. PU=University of the Punjab; LCWU= Lahore College for Women University; UMT= University of Management and 
Technology; GCU= Government College University; AIOU= Allama Iqbal Open University.

Table showed the demographical information of the respondents who were participating in this study. It was shown that 36 students with disabilities were males and 20 were females. Twenty-two students were enrolled in the University of the Punjab, Lahore, two students were from Lahore College for Women University, Lahore, seven were from University of Management and Technology, Lahore, sixteen students having disabilities were enrolled in Government College University, Lahore, six students were from Government College University, Faisalabad, and just three students were from Allama Iqbal Open University, Islamabad who were participating in this study. Out of 56 students, 50 were from urban, and six were from rural areas of the Punjab and their age range was between 20-30 years. The monthly income of their families was between Rs. 10,000-200,000. These participants were from M.A. Special Education $(\mathrm{N}=32)$, Islamic studies $(\mathrm{N}=2)$, Law $(\mathrm{N}=3)$, History $(\mathrm{N}=5)$, English $(\mathrm{N}=8)$, Economics $(\mathrm{N}=4)$, Urdu $(\mathrm{N}=2)$. Out of 56, 37 participants were from M.A. program, nine were from M.Phil and one student was enrolled in Ph.D.

Table 2: Summary Statistics of Perceived Effect of Monetary Aid on the Enthusiasm and Gratification of Disabled Students at University Level

\begin{tabular}{lcc}
\hline Variables & $M$ & $S D$ \\
\hline Effect of Financial Assistance on Motivation & 36.27 & 9.66 \\
Effect of Financial Assistance on Satisfaction & 36.92 & 10.17 \\
\hline
\end{tabular}

Table illustrated the results regarding the effect of monetary aid on the enthusiasm and gratification of disabled students at university level. It was shown that the mean score for the effect of financial assistance on the motivation $(M=36.27, S D=9.66)$ and satisfaction $(M=36.92, S D=10.17)$ of university students with disabilities was at highest level. Hence, it was concluded that the financial assistance received by the students with disabilities has positive effect on their motivation and satisfaction. Financial support being provided to students motivates them to survive in their studies and increase their level of satisfaction.

Table 3: Difference in the Effect of Financial Assistance Received by Male and Female Students with Disabilities on Their Motivation and Satisfaction

\begin{tabular}{|c|c|c|c|c|c|}
\hline \multirow[t]{2}{*}{ Variables } & Male (34) & Female (18) & \multirow[t]{2}{*}{$d f$} & \multirow[t]{2}{*}{ t-value } & \multirow[t]{2}{*}{$p$} \\
\hline & $M$ & $M$ & & & \\
\hline Motivation & 35.35 & 37.00 & 54 & -.59 & .560 \\
\hline Satisfaction & 37.00 & 35.78 & 54 & .42 & .677 \\
\hline
\end{tabular}

Table showed the results of independent sample t-test to identify the mean difference in the effect of monetary aid on the enthusiasm and gratification of students having disabilities in terms of their gender. The mean score for male $(M=35.35)$ and female $(M=37.00)$ regarding the effect of financial assistance on motivation was statistically not significant $t(50)=-.59, p=.560$. Similarly, the mean score for male $(M=37.00)$ and female $(M=35.78)$ regarding the effect of financial assistance on their satisfaction was also statistically not significant $t(54)=.42, p=.677$. So, on the based on these results research hypothesis that" there is a considerable statistical difference in the perceived effect of financial assistance received by male and female students with disabilities on their motivation and satisfaction at university level in Punjab." is rejected. It may be inferred that the financial assistance being provided to male and female students with disabilities has the same effect on their motivation and satisfaction at university level. The motivation and satisfaction level of male and female university students with disabilities was same who were receiving financial support.

Table 4: Difference in the Effect of Monetary Aid Received by Students having Disabilities Residing in Urban and Rural Parts on Their Enthusiasm and Gratification

\begin{tabular}{|c|c|c|c|c|c|}
\hline \multirow[t]{2}{*}{ Variables } & Urban (50) & Rural (6) & \multirow[t]{2}{*}{$d f$} & \multirow[t]{2}{*}{$t$-value } & \multirow[t]{2}{*}{$p$} \\
\hline & $M$ & $M$ & & & \\
\hline Motivation & 37.18 & 25.50 & 54 & 2.43 & .019 \\
\hline Satisfaction & 38.20 & 24.50 & 54 & 3.07 & .003 \\
\hline
\end{tabular}


Table presented the results of independent sample t-test to identify mean difference in the perceived effect of monetary aid on the enthusiasm and gratification of disabled students residing in the urban and rural areas. The mean score for students residing in the urban $(M=37.18)$ and rural areas $(M=25.50)$ about the effect of monetary aid on their enthusiasm was statistically not significant $t(54)=2.43, p=.019$. So, on the basis of these findings research hypothesis that" there is a statistically significant difference in the perceived effect of financial assistance being provided to rural and urban area students with disabilities on their motivation at university level in Punjab is rejected. On the other hand, the mean score for students with disabilities residing in the urban $(M=38.20)$ and rural areas $(M=$ 24.50) regarding the effect of financial assistance on their satisfaction was statistically significant $t(54)=3.07, p=$ .003. Therefore, on the basis of these results research hypothesis that" there is a statistically significant difference in the perceived effect of financial assistance being provided to rural and urban area students with disabilities on their satisfaction at university level in Punjab" is accepted. Hence, it was concluded that the effect of financial assistance was same on the motivation of students with disabilities residing in urban and rural areas. However, the effect of financial assistance was different on the level of satisfaction of students with disabilities in the urban and rural areas. The satisfaction level of urban area disabled students was high than the students with disabilities residing in rural area due to the financial assistance which they were receiving.

\section{Table 5: Difference on the Basis of Level of Education in the Perceived Effect of Monetary Aid on the Enthusiasm and Gratification of Students having Disabilities}

\begin{tabular}{lllll}
\hline Variable & $N$ & $d f$. & $F$ & $P$ \\
\hline Motivation & 56 & 2 & 1.25 & .297 \\
Satisfaction & 56 & 2 & 3.7 & .033 \\
\hline
\end{tabular}

Table clarified the results of ANOVA for identifying mean difference in the level of satisfaction and motivation of students with disabilities having different level of Education. It is evident that the difference is not statistically significant in level of motivation $F(2)=1.25, p=.297$ but statistically significant in the level of satisfaction $F(2)=$ $3.7, p<.05$. Based on these results, the research hypothesis that "there is a statistically significant difference on the basis of level of education in the perceived effect of financial assistance on the motivation of students with disabilities at university level in Punjab" is rejected. However, the research hypothesis that "there is a statistically significant difference on the basis of level of education in the perceived effect of financial assistance on the satisfaction of students with disabilities at university level in Punjab " is accepted. It is concluded that the effect of financial support on the motivation of students with disabilities was same in terms of their level of education (M.A, M. Phil, Ph.D). On the other hand, the effect of financial assistance on the satisfaction of students with disabilities was different with respect to their level of education (M.A, M.Phil, and Ph.D). It can be said that students with disabilities enrolled in Masters, M.phil and Ph.D were different in their level of satisfaction due to the financial assistance being provided to them.

Table 6: Difference in the Perceived Effect of Monetary Aid on the Enthusiasm and Gratification of Students having Disabilities Enrolled in Different Universities

\begin{tabular}{llllc}
\hline Variable & $N$ & $d f$. & $F$ & $P$ \\
\hline Motivation & 52 & 5 & .24 & .943 \\
Satisfaction & 52 & 5 & 2.8 & .026 \\
\hline
\end{tabular}

Table presented the results of ANOVA to identify mean difference in level of satisfaction and motivation of students with disabilities enrolled in different universities. It is evident that the mean difference is statistically not significant in level of motivation $F(5)=.24, p=.943$ but statistically significant in level of satisfaction $F(5)=2.8, p=.026$. On the basis of these results the research hypothesis that " there is a statistically significant difference in terms of university in the perceived effect of financial assistance on the motivation of students with disabilities at university level in Punjab " is rejected and the research hypothesis " there is a statistically significant difference in terms of university in the perceived effect of financial assistance on the satisfaction of students with disabilities at university level in Punjab" is accepted. It is concluded that students enrolled in different universities (PU, LCWU, UMT, GCU Lahore, GCU Faisalabad and AIOU) had different level of satisfaction whereas they were equally motivated due to financial assistance being provided to them. 


\begin{tabular}{|c|c|c|c|c|}
\hline Variable & $N$ & $d f$. & $F$ & $P$ \\
\hline Motivation & 56 & 5 & 1.26 & .276 \\
\hline Satisfaction & 56 & 5 & 3.3 & .023 \\
\hline
\end{tabular}

Table showed the results of ANOVA for identifying mean difference in the level of satisfaction and motivation of disabled students of different programs. It is evident that the difference is not statistically significant in the level of motivation $F(5)=1.26, p=.276$ but statistically significant in the level of satisfaction $F(5)=3.3, p=.023$. Based on these results, the research hypothesis that, "There is a statistically significant difference with respect to program in the perceived effect of monetary aid on the enthusiasm of students having disabilities at university level in Punjab." is rejected. However, the research hypothesis that "there is a statistically significant difference with respect to program in the perceived effect of financial assistance on the satisfaction of students with disabilities at university level in Punjab "is accepted. It is concluded that the effect of monetary support on the motivation of students who have disabilities was alike in terms of their program (M.A special education, Islamic Studies, Law, History, English, Economics, and Urdu). On the other hand, the effect of monetary aid on the gratification of students who had disabilities was diverse with respect to program (M.A Special Education, Islamic Studies, Law, History, English, Economics, and Urdu). Students enrolled in different programs had different level of satisfaction whereas they were equally motivated due to financial assistance being provided to them.

\section{Conclusions}

This study intended to examine the effect of monetary aid on the enthusiasm and gratification of students with disabilities at university level in Punjab. It was concluded that the financial assistance received by students with disabilities has positive effect on their motivation and satisfaction. Financial support being provided to students with disabilities motivates them to survive in their studies and increase their level of satisfaction. The motivation and satisfaction level of male and female university students with disabilities was same who were receiving financial support. Results further revealed that the effect of monetary aid was also same on the motivation of students with disabilities residing in urban and rural areas. However, the effect of monetary aid was different on the level of satisfaction of students having disabilities residing in the urban and rural areas. The satisfaction level of urban area disabled students was high than the students with disabilities residing in rural area due to the financial assistance which they were receiving. Furthermore, the effect of monetary support on the enthusiasm of students having disabilities was similar in terms of their level of education (M.A, M. Phil, Ph.D). On the other hand, the effect of monetary assistance on the gratification of students having disabilities was different with respect to their level of education (M.A, M.Phil, and Ph.D). It can be said that students with disabilities enrolled in Masters, M.phil and Ph.D were similar in their level of motivation. Nonetheless, their level of satisfaction was different due to the financial assistance being provided to them. Students enrolled in different universities (PU, LCWU, UMT, GCU Lahore, GCU Faisalabad and AIOU) had different level of satisfaction whereas they were equally motivated due to financial support being provided to them. It was also observed that the effect of monetary support on the motivation of students who had disabilities was alike in terms of their program (M.A special education, Islamic Studies, Law, History, English, Economics, and Urdu). On the other hand, the effect of financial assistance on the satisfaction of students with disabilities was diverse with respect to program (M.A Special Education, Islamic Studies, Law, History, English, Economics, and Urdu). Students enrolled in different programs had different level of satisfaction whereas they were equally motivated due to financial assistance being provided to them.

\section{Discussion on Major Findings}

The purpose of current research was to inspect the effect of monetary aid on the enthusiasm and gratification of disabled students at university level in Punjab. Results of the current study revealed that the financial assistance received by students with disabilities has positive effect on their motivation and satisfaction. Financial support being provided to students with disabilities motivates them to survive in their studies and increase their level of satisfaction. These findings of the current study are supported by the different researches (Kundu, Dutta, Schiro-Geist, \& Crandall, 2003; Olbrecht, Romano, \& Teigen, 2016). Another study conducted by Weaver (2013) gave opposite results to the findings of current study. According to the disability and development report of United Nations (2018), persons with disabilities belong to low-income families. It becomes a major obstacle in their way of getting higher education. So, financial aid promotes students with disabilities who are getting higher education and increases their level of 
motivation and satisfaction. Intrinsic and extrinsic motivations both are most important in educational settings (Ryan $\&$ Deci, 2000). The results of the current study also revealed that the motivation and satisfaction level of male and female university students with disabilities was same who were receiving financial support. Results further revealed that the effect of monetary assistance was also same on the enthusiasm of disabled students residing in urban and rural areas. However, the effect of monetary assistance was different on the level of satisfaction of students with disabilities residing in the urban and rural areas. The satisfaction level of urban area disabled students was higher than the students with disabilities residing in rural area due to the financial assistance which they were receiving. Furthermore, the effect of monetary support on the enthusiasm of students having disabilities was similar in terms of their level of education. On the other hand, the effect of monetary assistance on the satisfaction of students with disabilities was different with respect to their level of education. Students enrolled in different universities had different level of satisfaction whereas they were equally motivated due to financial support being provided to them. It was also observed that the effect of financial support on the motivation of students with disabilities was alike in terms of their program in which they were studying. On the other hand, the effect of monetary assistance on the gratification of students with disabilities was diverse with respect to their program as M.A Special Education, Islamic Studies, Law, History, English, Economics, and Urdu. Students enrolled in different programs had different level of satisfaction whereas they were equally motivated due to financial assistance being provided to them. Bittinger (2016) contacted a study to examine the financial aid received by students with disabilities which supported the results of the current study.

\section{Recommendations}

Following recommendations were made after getting insight into the findings of this study.

- Financial aid administrators who are working with professional associations should provide training opportunities to educational institutes. It will be helpful for them to understand the special problems faced by low-income students with disabilities.

- Government should improve the higher education opportunities for low-income students with disabilities by providing them financial assistance.

- Higher education commission (HEC) should take initiative to implement policies regarding the financial assistance for students with disabilities to increase their motivation and satisfaction towards studies at advance level. In this way, they will be able to contribute in the economic development of Pakistan.

- Government should also provide more sources of income to low-income families of students with disabilities who are studying at higher education level.

- Future research should be conducted in different contexts and environment to investigate the problems of students with disabilities from low-income families.

\section{References}

Bigaj, S. J., \& Bazinet, G. P. (1993). Teaming in Two-Year Postsecondary Settings: An Approach to Providing Effective and Efficient Services for Students with Disabilities. Journal for Vocational Special Needs Education, 15(3), 40-49.

Bittinger, J. (2016). Financial Aid Received by Students with Disabilities, Association for the Study of Higher Education (ASHE) Annual Conference, Columbus, OH, Nov. 2016. University of Massachusetts Amherst, Amherst: Running head: aid and disability.

Bureau of Labor Statistics. (2012). News release: The employment situation December 2011. Washington, DC: Bureau of Labor Statistics, U.S. Department of Labor.

Deci, E. L., \& Ryan, R. M. (2000). The 'what' and 'why' of goal pursuits: Human needs and the self-determination of behavior. Psychological Inquiry, 11, 227-268.

Deci, E. L., \& Ryan, R. M. (2008). Facilitating optimal motivation and psychological well-being across life's domains. Canadian Psychology, 49, 14-23.

DeFur, S. H., Getzel, E. E., \& Trossi, K. (1996). Making the postsecondary education match: A role for transition planning. Journal of Vocational Rehabilitation, 6 (3), 231-241. 
Financial Aid for Students with Disabilities. (2015). The heath resource center at the national youth transitions center. Retrieved from https://www.easterseals.com/shared-components/document-library/planning-ahead-financialaid.pdf

Getzel, E. E., \& Kregel, J. (1996). Transitioning from the academic to the employment setting: The employment connection program. Journal of Vocational Rehabilitation, 6(3), 273-287.

Government of Pakistan. (2002). National policy for persons with disabilities, 2002. Ministry of Women Development Social Welfare and Special Education.

Hasan, N., Malik, S. A., \& Khan, M. M. (2013). Measuring relationship between students' satisfaction and motivation in secondary schools of Pakistan. Middle-East Journal of Scientific Research, 18(7), 907-915.

Kundu, M., Dutta, A., Schiro-Geist, C., \& Crandall, L. (2003). Disability-related services: Needs and satisfaction of post-secondary students. Rehabilitation Education-New York-Pergamon Press-, 17(1), 45-54.

Lichtenstein, S., \& Michaelides, N. (1993). Transition from school to young adulthood: Four case studies of young adults labelled mentally retarded. Career Development for Exceptional Individuals, 16(2), 183-195.

Madaus, J. W., Grigal, M., \& Hughes, C. (2014). Promoting access to postsecondary education for low-income students with disabilities. Career Development and Transition for Exceptional Individuals, 37(1), 50-59.

McGuire, J. M., Norlander, K. A., \& Shaw, S. F. (1990). Postsecondary education for students with learning disabilities: Forecasting challenges for the future. Learning Disability Focus, 5(2), 69-74.

National Center for Educational Statistics. (2016). Digest of education statistics, 2014 (2016-006). Washington, DC: National Center for Education Statistics, U.S. Department of Education.

Newman, L., Wagner, M., Cameto, R., Knokey, A., \& Shaver, D. (2010). Comparisons across time of the outcomes of youth with disabilities up to 4 years after high school. A report of findings from the National Longitudinal Transition Study (NLTS) and the National Longitudinal Transition Study-2 (NLTS2) (NCSER 2010-3008). Menlo Park, CA: SRI International.

Newman, L., Wagner, M., Knokey, A., Marder, C., Nagle, K., Shaver, D. ..., \& Schwarting, M. (2011). The post-high school outcomes of young adults with disabilities up to 8 years after high school. A report from the National Longitudinal Transition Study-2 (NLTS2) (NCSER 2011-3005). Menlo Park, CA: SRI International.

Olbrecht, A. M., Romano, C., \& Teigen, J. (2016). How money helps keep students in college: The relationship between family finances, merit-based aid, and retention in higher education. Journal of Student Financial Aid, 46(1), 2-16.

O'Shea, A., \& Meyer, R. H. (2016). A Qualitative Investigation of the Motivation of College Students with Nonvisible Disabilities to Utilize Disability Services. Journal of Postsecondary Education and Disability, 29(1), 5-23.

Parker, R. M., \& Szymanski, E. M. (1998). Rehabilitation counseling: Basics and beyond. Austin, TX: Pro-Ed.

Ryan, R.M. \& Deci, E.L. (2000). Intrinsic and extrinsic motivations: Classic definitions and new directions. Contemporary Educational Psychology, 25, 54-67. doi:10.1006/ceps.1999.1020

Smith, F. A., Grigal, M. \& Sulewski, J. (2012). The impact of postsecondary education on employment outcomes for transition-aged youth with and without disabilities: A secondary analysis of American Community Survey data (Think College Insight Brief, No. 15). Boston, MA: Institute for Community Inclusion, University of Massachusetts Boston.

Wagner, M., Newman, L., Cameto, R., Levine, P., \& Marder, C. (2007). Perceptions and Expectations of Youth with Disabilities. A Special Topic Report on Findings from the National Longitudinal Study-2 (NLTS2): Chapter 6-Youth's Expectations for the Future. Journal for Vocational Special Needs Education, 30(1), 18-27.

Weaver, A. E. (2013). The Relationship Between Students' Financial Responsibility for College and Levels of Academic Motivation and Success (Doctoral dissertation, Ashland University).

Wolanin, T. R. (2005). Students with disabilities: Financial aid policy issues. Journal of Student Financial Aid, 35(1), 17-26. 
World Health Organization. (2015). WHO global disability action plan 2014-2021: Better health for all people with disability. World Health Organization. 